\title{
PEMANFAATAN BEBERAPA TANAMAN HERBAL SEBAGAI ZAT AKTIF DALAM BEBERAPA SEDIAAN PENGHARUM RUANGAN SEBAGAI PENGUSIR NYAMUK
}

\section{UTILIZATION OF SOME HERBAL PLANTS AS ACTIVE MATERIALS IN SOME SPACE INCLUDING PROVISIONS AS MOSQUITO REPELLENT}

\author{
Isna Jati Asiyah ${ }^{1)}$, Desi Purwaningsih ${ }^{2)}$, Destik Wulandari ${ }^{3)}$ \\ ${ }^{1,2,3}$ Fakultas Farmasi Universitas Setia Budi Surakarta \\ ${ }^{1}$ Email: : Isna_jati@yahoo.co.id
}

\begin{abstract}
Abstrak: Nyamuk merupakan salah satu penyebab permasalahan masyarakat karena dapat menimbulkan berbagai penyakit dan mengganggu kenyamanan. Nyamuk dapat ditimbulkan karena kurangnya kebersihan lingkungan di masyarakat. Sekarang ini banyak masyarakat yang takut untuk menggunakan produk penolak nyamuk bentuk jadi yang telah dibuat dan dikeluarkan oleh pabrik atau industri tertentu. Kandungan kimia yang terkandung didalam sediaan tersebut menjadi alasan mengapa masyarakat mencari alternatif lain untuk membuat penolak nyamuk dengan menggunakan bahan alami yang lebih aman. Salah satu usaha pencegahan dan pengendalian terhadap serangan nyamuk yaitu dengan menggunakan pengharum ruangan dalam bentuk sediaan gel maupun lilin yang sekaligus dapat digunakan untuk pengusir nyamuk. Sediaan gel dan lilin pengharum ruangan pembuatanya cukup mudah dan bahan-bahan juga mudah didapatkan sehingga dapat dibuat sendiri oleh masyarakat. Keuntungan yang diperoleh masyarakat dengan pembuatan gel dan lilin pengharum ruangan secara mandiri yaitu aroma dapat disesuaikan dengan yang diinginkan, selain itu juga dapat dikembangkan menjadi home industry. Tujuan kegiatan ini adalah meningkatkan kesadaran masyarakat terhadap pemahaman pentingnya menjaga kebersihan lingkungan untuk menciptakan kesehatan pada keluarga serta melatih usaha pembuatan gel dan lilin aromaterapi dengan bahan alami, menghasilkan produk yang dapat digunakan sendiri maupun dikembangkan menjadi home industry. Kegiatan ini dilakukan dengan cara penyuluhan kebersihan lingkungan dan workshop pembuatan gel dan lilin aromaterapi sebagai alternatif pengusir nyamuk. Hasil yang diperoleh yaitu peningkatan pemahaman masyarakat terhadap kebersihan lingkungan, dihasilkan produk gel dan lilin aromaterapi sebagai pengusir nyamuk yang produksinya dapat dikembangkan dalam skala industri rumah tangga masyarakat Bibis Luhur RW 22 Nusukan.
\end{abstract}

Kata Kunci: Gel, Lilin, Aromaterapi

Abstract: Mosquitoes are one of the causes of community problems because they can cause various diseases and interfere with comfort. Mosquitoes can be caused due to lack of environmental cleanliness in the community. Nowadays many people are afraid to use mosquito repellent products that have been made and 


\section{INTEGRITAS : Jurnal Pengabdian}

Vol 5 No 1 Juli 2021

ISSN 2580 - 7978 (cetak) ISSN 2615 - 0794 (online)

released by certain factories or industries. The chemical content contained in these preparations is the reason why people look for other alternatives to make mosquito repellents by using safer natural ingredients. One of the efforts to prevent and control mosquito attacks is by using air freshener in the form of gel and candle preparations. Gel and candle fragrances for the manufacture of the room are quite easy and the ingredients are also easily obtained so that it can be made by the community. The purpose of this activity is to increase public awareness of the importance of maintaining environmental hygiene to create health for the family and train the business of making aromatherapy gels and candles with natural ingredients, produce products that can be used alone or developed into a home industry. This activity was carried out by means of environmental hygiene counseling and a workshop on making aromatherapy gels and candles as an alternative mosquito repellent. The results obtained are increased public understanding of environmental cleanliness, aromatherapy gel and candle products are produced as mosquito repellents whose production can be developed on the scale of the home industry of Bibis Luhur RW 22 Nusukan.

Keywords: Wax, Gel, Aromateraphy

\section{PENDAHULUAN}

Bibis Luhur Rw 22 Kelurahan Nusukan adalah sebuah perkampungan yang berada tidak jauh dari lokasi kampus Universitas Setia Budi, berjarak kurang lebih $1 \mathrm{Km}$ dari kampus Universitas Setia Budi. Kampung dengan kepadatan penduduk yang tinggi dan mayoritas warga kampung adalah pedagang dengan tingkat penghasilan yang rendah. Pengangguran juga masih cukup banyak dikampung ini dan banyak ibu rumah tangga yang tidak bekerja. Dengan tingkat kepadatan penduduk yang tinggi dan perekonomian yang rendah, secara tidak langsung juga berdampak terhadap kebersihan lingkungan yang kurang. Penyakit-penyakit yang ditularkan oleh nyamuk merupakan salah satu masalah kesehatan yang cukup penting. Penyakit yang ditularkan melalui nyamuk diantaranya adalah Malaria, Demam Berdarah Dengue, dan Filaris (Susanna dkk, 2003).

Hasil survei yang telah dilakukan tim PPM Universitas Setia Budi menunjukkan bahwa masih dijumpai jentik nyamuk di penampungan air sehingga warga sangat menantikan transfer ilmu dari Universitas Setia Budi dalam bentuk pengabdian kepada masyarakat terkait dengan upaya untuk peningkatan pengetahuan tentang kesehatan untuk mengurangi dan menghilangkan nyamuk 
INTEGRITAS : Jurnal Pengabdian

Vol 5 No 1 Juli 2021

ISSN $2580-7978$ (cetak) ISSN 2615-0794 (online)

serta motivasi perintisan home indutry dalam upaya peningkatan perekonomian warga.

Permasalahan yang dihadapi Mitra adalah tingkat perekonomian yang rendah serta pengetahuan dan kesadaran akan kebersihan yang rendah sehingga berdampak pada bau di dalam rumah yang kurang enak dan munculnya berbagai hewan penyebab penyakit, diantaranya yaitu nyamuk. Perlu pelatihan dan motivasi untuk menciptakan peluang usaha rumahan (home industry) dengan produk-produk yang dapat digunakan untuk mengharumkan ruangan sekaligus untuk mengusir nyamuk dan menambah income penduduk.

Pengharum ruangan dalam bentuk sediaan gel dan lilin memiliki beberapa keunggulan diantaranya yaitu penggunaannya lebih praktis dan mudah dibandingkan dengan pengharum ruangan dalam bentuk lainnya. Selain itu, pengharum ruangan dalam bentuk sediaan gel dan lilin ini lebih mudah dalam hal penyimpanan dan pengemasannya. Lilin memiliki manfaat lebih karena selain dapat digunakan sebagai penerang, lilin tersebut juga dapat digunakan sebagai pengharum ruangan dan pengusir nyamuk. Sediaan pengharum ruangan pembuatannya cukup mudah dan bahan-bahan juga mudah didapatkan sehingga dapat dibuat secara mandiri oleh masyarakat. Keuntungan yang diperoleh masyarakat dengan pembuatan gel dan lilin pengharum ruangan secara mandiri yaitu aroma dapat disesuaikan dengan yang diinginkan. Beberapa aroma yang dapat digunakan sebagai pengaharum ruangan sekaligus pengusir nyamuk adalah : 1. Minyak Sereh Wangi (Citronella)

Nama sereh wangi adalah Cymbopogon nardus L., termasuk dalam suku Poaceae (rumput-rumputan). Varietas sereh wangi yang paling dikenal adalah varitas Mahapegiri (java citronella oil) dan varitas Lenabatu (cylon citronella oil). Minyak sereh wangi dapat digunakan sebagai penolak gigitan nyamuk karena mengandung sitronellal dan geraniol. Minyak sereh wangi mengandung sitronela (35\%) dan geraniol (35-40\%). Zat sitronelal ini memiliki sifat racun kontak. Sebagai racun kontak, ia dapat menyebabkan kematian akibat kehilangan cairan secara terus-menerus sehingga tubuh nyamuk kekurangan 


\section{INTEGRITAS : Jurnal Pengabdian}

Vol 5 No 1 Juli 2021

ISSN 2580 - 7978 (cetak) ISSN 2615 - 0794 (online)

cairan. Hal ini dapat terjadi setelah nyamuk mencium aroma ekstrak sereh wangi. tanaman ini mempunyai aroma yang sangat wangi akan menyebabkan nyamuk menolak karena baunya (Pinardi et al, 2010).

2. Minyak Lavender

Minyak lavender adalah minyak atsiri yang diperoleh dari bunga lavender (Lavandula latiofola). Minyak lavender banyak digunakan dalam produksi dari parfum dan dapat digunakan dalam aromaterapi. Wangi lavender memiliki efek menenangkan yang dapat membantu relaksasi. Hal ini juga dapat membantu untuk mengurangi rasa sakit dari sakit kepala ketegangan saat menghirup sebagai uap atau diencerkan dan digosok pada kulit. Komposisi utama dalam minyak lavender adalah linalool yang mampu mengendorkan dan melemaskan sistem kerja uraturat syaraf dan otot-otot yang tegang. Karena kandungan atau komposisi utama inilah bunga lavender sering digunakan sebagai bahan lotion anti nyamuk, aromaterapi, parfum, minyak gosok, ramuan untuk mandi, dan obat-obatan.

\section{Minyak Lemon}

Minyak lemon diambil dari bagian kulit buahnya dengan cara pengepresan dingin maupun penyulingan uap. Tetapi jika digunakan penyulingan uap akan menghasilkan minyak dengan kualitas rendah. Rendemen minyak berkisar antara $0.35 \%-0.65 \%$ (berdasarkan berat buah lemon). Minyak lemon termasuk ke dalam genus Citrus. Komposisi senyawa yang terdapat di dalam minyak atsiri yang dihasilkan dari kulit buah tanaman genus Citrus berdasarkan penelitian yang pernah dilakukan di antaranya adalah limonen, sitronelal, geraniol, linalol, $\alpha$ pinen, mirsen, $\beta$-pinen, sabinen, geranil asetat, nonanal, geranial, $\beta$-kariofilen, dan $\alpha$-terpineol (Chutia dkk., 2009). Komponen penyusun minyak lemon berdasarkan hasil GCMS adalah limonene dengan jumlah $76.28 \%$, mirsen $1.33 \%$, osimen $1.37 \%$, linalool $0.56 \%$, nonanal $0.54 \%$, geraniol $0.98 \%$, $\alpha$-sitral $5.58 \%$, dan zsitral 7.70\% (Sukmawaty, 2002). Menurut Oktovina (2006), minyak jeruk lemon (Citrus limon) dihasilkan dengan teknik ekstraksi dari bagian kulit buah. Komponen kimia bahan aktifnya meliputi senyawa limonene, sitral, dan sitronellal. 
INTEGRITAS : Jurnal Pengabdian

Vol 5 No 1 Juli 2021

ISSN $2580-7978$ (cetak) ISSN 2615-0794 (online)

Warna cairannya hijau kekuningan hingga kecoklatan. Wewangiannya beraroma jeruk asam yang segar dan khas.

Minyak atsiri lemon dapat digunakan sebagai pengharum ruangan, bahan parfum, dan penambah cita rasa pada makanan. Minyak atsiri jeruk lemon juga bermanfaat bagi kesehatan, yaitu untuk aromaterapi. Aroma jeruk lemon dapat menstabilkan sistem syaraf, menimbulkan perasaan senang dan tenang, meningkatkan nafsu makan, dan menyembuhkan penyakit. Manfaat bagi kesehatan tersebut karena minyak atsiri jeruk lemon mengandung senyawa limonen. Minyak atsiri jeruk lemon juga mengandung linalool, linalil, dan terpineol yang memiliki fungsi sebagai penenang (sedatif), serta sitronela sebagai penenang dan pengusir nyamuk.

\section{METODE}

Solusi untuk permasalahan yang dihadapi Mitra yaitu perlunya pelatihan dan motivasi untuk menciptakan peluang usaha rumahan (home industry) dengan produk yang dapat digunakan untuk mengharumkan ruangan dan sebagai pengusir nyamuk sekaligus menambah income penduduk yaitu berupa gel dan lilin aromaterapi.

Pada pelaksanaan PPM ini dilakukan penyuluhan, pelatihan dan pemberian alat produksi. Target Mitra adalah kelompok ibu rumah tangga di Wilayah Bibis Luhur Rw 22 Kelurahan Nusukan, berperan sebagai peserta penyuluhan dan pelatihan, yang nantinya diharapkan menjadi kelompok produsen gel dan lilin pengharum ruangan sebagai pengusir nyamuk berskala home industry. Langkahlangkah yang dilakukan sebagai berikut:

1. Kelompok ibu rumah tangga diberikan pengetahuan tentang dampak dari kebersihan lingkungan yang rendah.

2. Kelompok ibu rumah tangga diberikan pengetahuan tentang penyakit-penyakit yang berpotensi muncul yang disebabkan lingkungan yang kurang bersih. Penekanan pada penyakit yang disebabkan nyamuk.

3. Memperkenalkan sediaan - sediaan yang dapat digunakan untuk mengusir nyamuk. 


\section{INTEGRITAS : Jurnal Pengabdian}

Vol 5 No 1 Juli 2021

ISSN 2580 - 7978 (cetak) ISSN 2615 - 0794 (online)

4. Memperkenalkan sediaan gel dan lilin yang digunakan untuk mengharumkan ruangan sekaligus untuk mengusir nyamuk.

5. Dilakukan pelatihan tentang bagaimana cara membuat gel dan lilin pengharum ruangan sebagai pengusir nyamuk yang komposisi zat aktifnya berasal dari tanaman.

\section{Pembuatan Gel Aromaterapi :}

Parafin padat dimasukkan dalam penangas panci (kaca/stainlees/aluminium) dipanaskan dengan cara ditim (di atas panci yang sudah diisi air). Karagenan dan gelatin dikembangkan dalam air panas. Paraffin yang sudah meleleh ditambah dengan karagenan dan gelatin yang sudah mengembang dicampur dalam gelas kaca. Setelah hangat ditambahkan minyak sereh wangi, minyak jeruk, minyak lavender. Tuang dalam cetakan tunggu sampai dingin. Masukkan dalam kemasan.

\section{Pembuatan Lilin Aromaterapi}

Bahan dasar lilin paraffin dan white oil ditim sampai leleh dengan cara isi air ke panci sebanyak setengahnya atau atur supaya tidak tumpah. Taruh wadah kaca yang berisi paraffin. Lalu masukkan pewarna dan bila mau harum bisa ditambahkan parfum dan bila mau digunakan untuk aroma terapi masukkan minyak essential aromaterapi, setelah itu tuang dicetakan atau gelas. Dibiarkan beberapa jam baru keluarkan dari cetakan (Minah dkk., 2017)

6. Pemberian sarana untuk pembuatan gel dan lilin pengharum ruangan sebagai pengusir nyamuk berupa kompor gas, panci, bahan-bahan pembuatan gel dan lilin, pengemas gel, dan cara pembuatannya.

Untuk melihat keberhasilan Program Pengabdian bagi Masyarakat ini dilakukan pemantauan hasil berkala dan kerjasama antara kelompok ibu rumah tangga di Bibis Luhur RW 22 Kelurahan Nusukan dan Universitas Setia Budi dalam hal pemantauan mutu produk yang dihasilkan. 
INTEGRITAS : Jurnal Pengabdian

Vol 5 No 1 Juli 2021

ISSN 2580-7978 (cetak) ISSN 2615-0794 (online)

\section{HASIL DAN PEMBAHASAN}

Kegiatan pengabdian masyarakat dengan tema "Pemanfaatan Beberapa Tanaman Herbal sebagai Zat Aktif dalam Beberapa Sediaan Pengharum Ruangan sebagai Pengusir Nyamuk" dilaksanakan di Kampung Bibis Luhur RW 22, Kelurahan Nusukan, Banjarsari, Surakarta. Pelaksanaan kegiatan pengabdian ini meliputi beberapa tahapan diantaranya yaitu koordinasi dengan pihak Ketua RW 22 Bibis Luhur terkait penentuan tanggal pelaksanaan pengabdian, perijinan pihak Kelurahan Nusukan, pembagian undangan, pelaksanaan penyuluhan dan pelatihan, serta evaluasi kegiatan.

Sebelum kegiatan pengabdian dilaksanakan di masyarakat Bibis Luhur RW 22 Nusukan, terlebih dahulu dilakukan orientasi untuk mendapatkan formula yang optimal dalam pembuatan sediaan pengharum ruangan sebagai pengusir nyamuk. Sediaan yang akan dibuat berupa lilin dan gel aromaterapi dengan berbagai jenis aroma. Aroma yang digunakan meliputi aroma lavender, jeruk dan sereh dimana ketiga aroma tersebut merupakan aroma yang tidak disukai oleh nyamuk.

Kegiatan pengabdian masyarakat dilaksanakan pada hari Jum'at tanggal 13 Desember 2019 pukul 15.00 - 18.00 WIB di rumah salah satu warga RT 02 RW 22 Bibis Luhur yaitu rumah Ibu Dalinem. Metode pelaksanaan kegiatan meliputi pemberian materi tentang bahaya gigitan nyamuk, pentingnya menjaga kebersihan lingkungan, penggunaan produk pengharum ruangan sebagai bahan alternatif pengusir nyamuk, serta pelatihan pembuatan lilin dan gel aromaterapi. Selanjutnya ibu-ibu praktek membuat lilin dan gel aromaterapi yang dilakukan secara mandiri dengan pendampingan.

Program kegiatan pengabdian masyarakat dihadiri oleh 27 peserta warga RW 22 Kelurahan Nusukan. Peserta kegiatan terdiri dari warga RT 01 sampai dengan RT 05. Adapun urutan acara kegiatan pengabdian yaitu :

1. Pembukaan dan pengarahan singkat dari Ibu ketua RW 22 Bibis Luhur

2. Pemberian materi penyuluhan pentingnya menjaga kebersihan lingkungan, bahaya nyamuk, dan pembuatan produk sediaan pengusir nyamuk 


\section{INTEGRITAS : Jurnal Pengabdian}

Vol 5 No 1 Juli 2021

ISSN 2580 - 7978 (cetak) ISSN 2615 - 0794 (online)

3. Pemberian motivasi pengembangan home industry

4. Diskusi

5. Pelatihan pembuatan gel dan lilin aromaterapi serta diskusi

6. Penutup

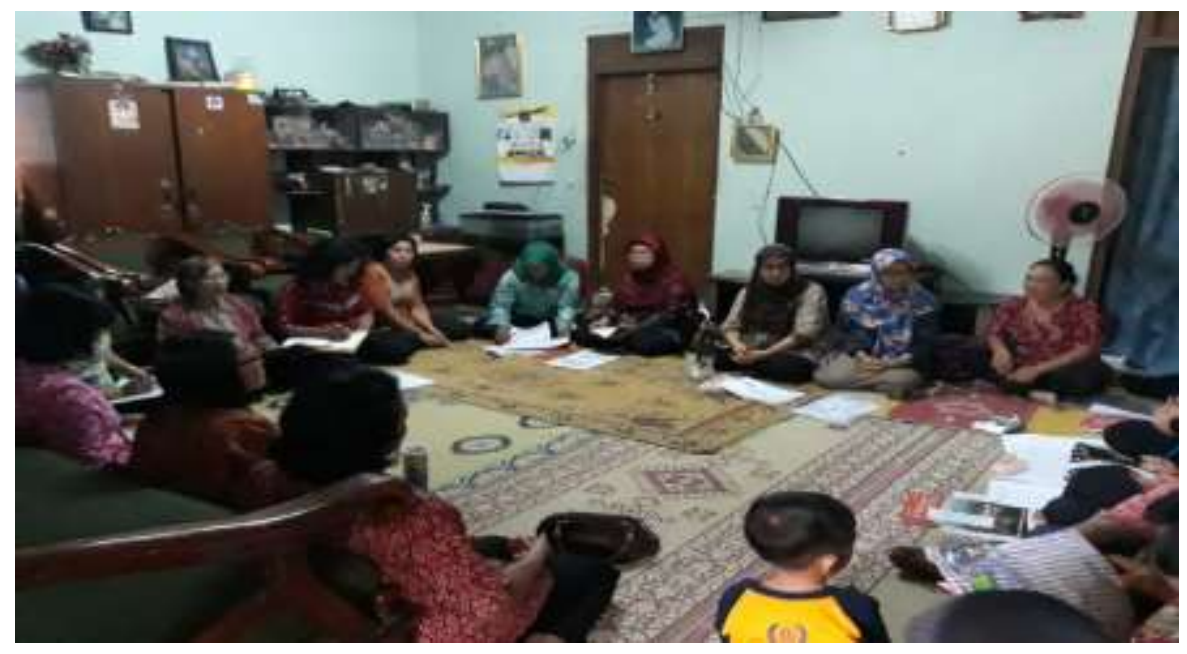

Gambar 1. Kegiatan penyuluhan
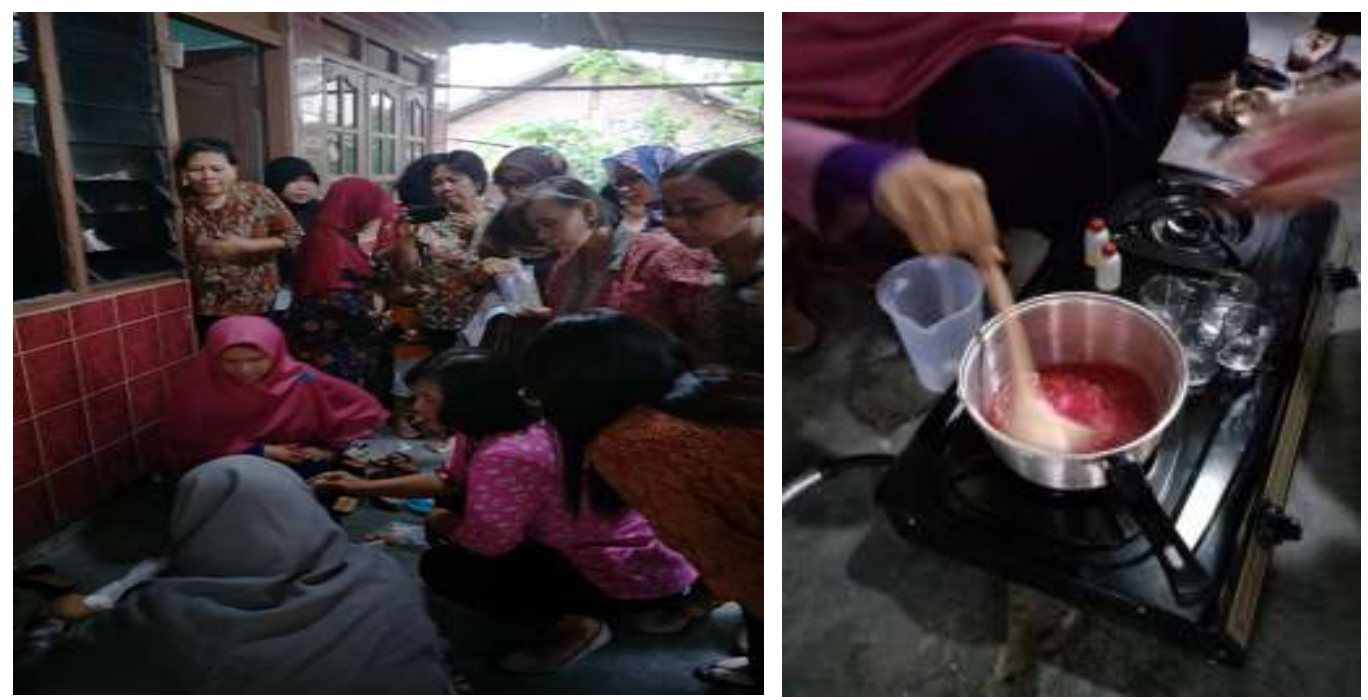

Gambar 2. Kegiatan pelatihan pembuatan gel dan lilin aromaterapi 


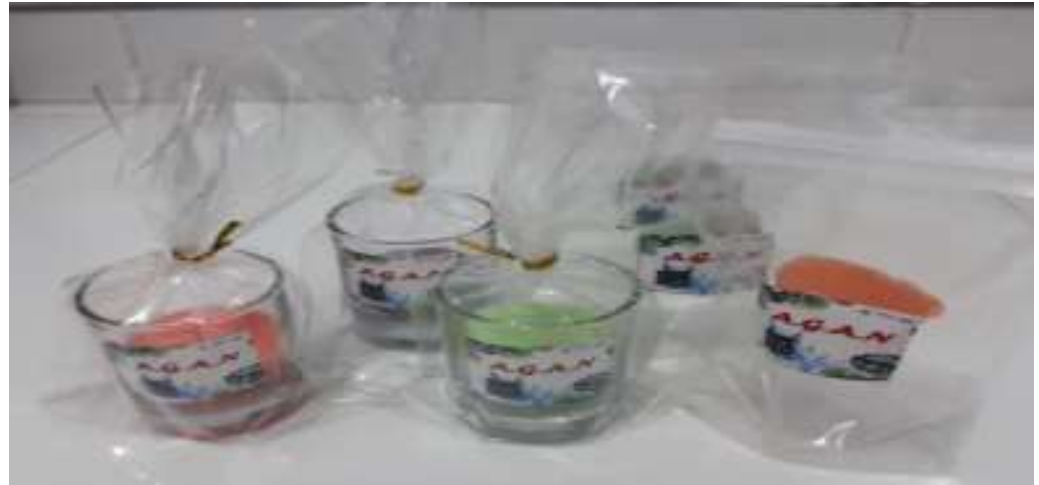

Gambar 3. Produk lilin dan gel aromaterapi

Materi pelatihan berupa pemberian leaflet serta dilanjutkan dengan pelatihan pembuatan lilin dan gel aromaterapi. Peserta memperhatikan, antusias dan berperan aktif untuk bertanya tentang seputar pembuatan gel dan lilin aromaterapi. Ketertarikan dan peran aktif dari para peserta terhadap penyuluhan dan pelatihan pembuatan sediaan pengaharum ruagan sebagai pengusir nyamuk ini diharapkan bisa menjadi peluang usaha rumah tangga di lingkungan RW 22 Kelurahan Nusukan, yang merupakan salah satu target luaran dalam kegiatan pengabdian pelatihan pembuatan lilin dan gel aromaterapi.

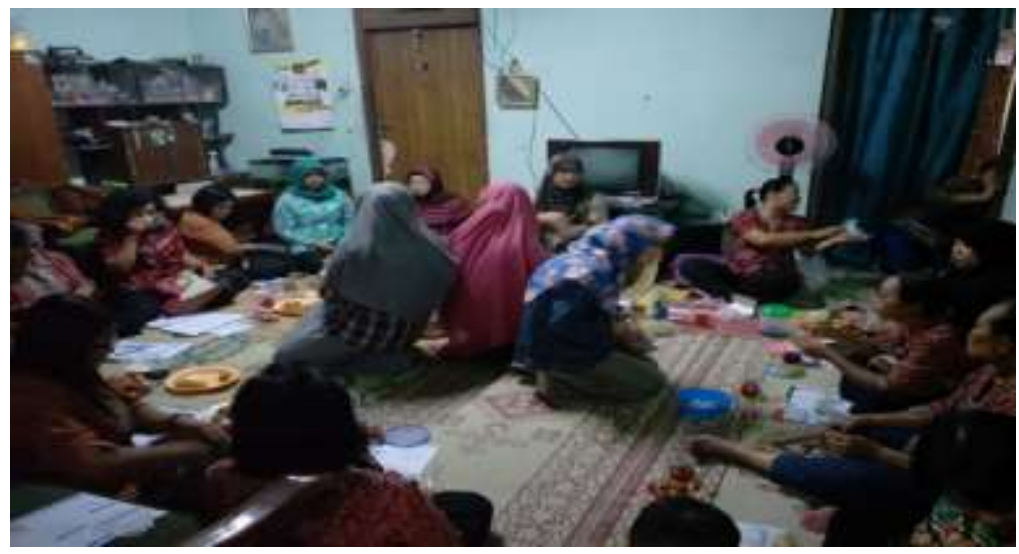

Gambar 4. Kegiatan diskusi

Penyuluhan dan pelatihan pembuatan lilin dan gel aromaterapi pengusir nyamuk sebagai rintisan home industry ditindaklanjuti dengan menghibahkan peralatan berupa kompor, tabung gas, panci, pengaduk, cetakan gel, wadah lilin aromaterapi, dan bahan-bahan pembuat lilin dan gel aromaterapi yang nantinya diharapkan warga bisa membuat sediaan tersebut untuk kepentingan sendiri dan 


\section{INTEGRITAS : Jurnal Pengabdian}

Vol 5 No 1 Juli 2021

ISSN 2580 - 7978 (cetak) ISSN 2615 - 0794 (online)

harapannya bisa memproduksi dalam jumlah besar untuk diperdagangkan sehingga bisa menambah penghasilan.

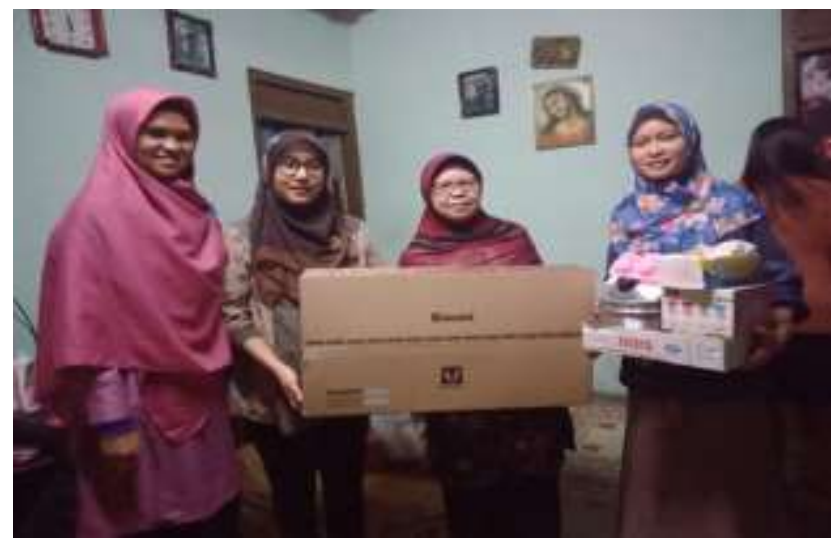

Gambar 5. Pemberiaan alat dan bahan untuk pembuatan lilin dan gel aromaterapi secara mandiri oleh masyarakat

\section{Evaluasi kegiatan}

Evaluasi kegiatan pengabdian masyarakat dilakukan dengan cara pemberian kuesioner kepada seluruh peserta penyuluhan dan pelatihan. Hasil kuesioner menunjukkan tingkat respon kepuasan yang tinggi oleh ibu-ibu terhadap kegiatan yang telah dilaksanakan dan harapannya untuk selanjutnya tetap diadakan kegiatan-kegiatan yang bermanfaat bagi masyarakat di RW 22 Nusukan Surakarta.

\section{KESIMPULAN}

Kegiatan pengabdian pelatihan pembuatan lilin dan gel aromaterapi sebagai pengusir nyamuk di Kampung Bibis Luhur RW 22, Nusukan, Banjarsari, Surakarta terlaksana dengan baik dan lancar. Peserta antusias dengan penyuluhan dan pelatihan pembuatan lilin dan gel aromaterapi. Peserta berperan aktif dalam pelatihan pembuatan lilin dan gel aromaterapi serta mampu membuat produk secara mandiri.

\section{UCAPAN TERIMA KASIH}

Tim Pengabdian Maysarakat menyampaikan banyak terima kasih kepada LPPM Universitas Setia Budi Surakarta yang telah membiayai program ini 
sehingga kegiatan pengabdian kepada masyarakat ini bisa berjalan dengan baik dan bermanfaat bagi masyarakat maupun perkembangan ilmu pengetahuan.

\section{DAFTAR PUSTAKA}

Chutia, M., Bhuyan, D. P., Pathak, M. G., Sarma, T. C., Boruah P. (2009). Antifungal Activity and Chemical Composition of Citrus reticulata Blanco Essential Oil Against Phytopathogens from North East India. Food Science and Technology J, 42, 777-780.

Dewan Atsiri dan IPB. (2010). Minyak Atsiri Indonesia Tanaman-Tanaman Penghasil Minyak Atsiri di Indonesia. [Online]. Tersedia pada: http://budidayabenihtanaman.blogspot.com/2010/08/sumber-dewanatsiri-Indonesia-dan-ipb.html

Fardiaz, D. (1989). Hidrokoloid. Bogor: Pusat Antar Universitas Pangan dan Gizi, Institut Pertanian Bogor. Laboratorium Kimia dan Biokimia Pangan

Minah, F.N., Tri P., Siswi A., Musayyaroh, Rini K., Elvianto, Istnaeny H., dan Endah K.R. (2017). Pembuatan Lilin Aromaterapi Berbasis Bahan Alami. Jurnal Industri Inovatif, 1(7), 29-34

Susanna D, Rahman A, Pawenang ET. (2003). Potensi daun pandan wangi untuk membunuh larva nyamuk Aedes aegypti. Jurnal Ekologi Kesehatan, 2(2), $228-231$

Van de Velde, F., and G.A. De Ruiter. (2005). Carrageenan. Steinbüchel A, Rhee SK, editor. Didalam Polysaccharides and Polyamides in the Food Industry Vol 1. Weinheim: Wiley-VCH Verlag GmbH and Co. KGaA 